\title{
Malta (Citrus sinensis): An Important but Underrated Fruit of Uttarakhand, India
}

\author{
Suraj Goswami, Arvind Bijalwan* and Kalpana
}

College of Forestry VCSG Uttarakhand University of Horticulture and Forestry, Ranichauri, Tehri Garhwal-249199, Uttarakhand, India

*Corresponding author

A B S T R A C T

\begin{tabular}{|l|}
\hline Ke y w o r d s \\
Malta, \\
Citrus sinensis (L.), \\
Underrated Fruit
\end{tabular}

Malta (Citrus sinensis), a delicious and nutritious citrus fruit of hill areas of Uttarakhand, India. Malta is a valuable fruit but still underrated and struggling hard for its proper marketing and business. This article deals with the importance, use, marketing challenges and other issues faced by Malta fruit. The role of post-harvest management, value addition and marketing strategies have also discussed in this article for proper utilization of potential of Malta fruit.

\section{Introduction}

Malta, scientifically known as Citrus sinensis (L.) Osbeck is an important seasonal citrus fruit familiar to the hilly areas of Uttarakhand, India. The fruit is nutritive, rich in vitamins usually eaten during winters and preferred by the local people of Uttarakhand hills due to its distinct sweet-sour taste. This fruit tree is commonly found in scattered manner in kitchen gardens and homegardens, however, it could not attain a significant place in urban as well as in local markets which has reduced its popularity as a commercial fruit crop. The present article deals with the issues faced by malta fruit due to the lack of proper attention given for its production, value addition and the establishment of a proper marketing channel. Despite being as tasty and nutritious as other citrus fruits, malta fruit is lagging far behind. There is a need to improve the production, management practices and the marketing of this fruit, moreover, there is a vast potential for increasing its production and marketing.

Malta is also known as sweet orange is one of among the important members of family 
Rutaceae. This fruit is distributed in Himalayan states of India like- Jammu \& Kashmir, Himachal Pradesh, Uttarakhand and Sikkim (Shah, 2014). It grows as a shrub and tree with white flowers and takes upto 5-6 years to reach the reproductive phase from the time of planting. Flowering on this tree occurs from March to May and the fruits are harvested in November - December. This fruit tree is commonly grown in the homegardens and the kitchen gardens in the hilly areas of Uttarakhand. In the hilly regions of Uttarakhand, people can be seen consuming the slices of malta fruit marinated with homemade salt, sugar, honey or sometimes cream during the sunny winters. This fruit is also consumed and used in many forms likejuice, squash, candy, jam, essential oil, peel powder etc. Every $100 \mathrm{~g}$ of malta squash and ready to serve (RTS) drinks contain about total soluble solids $\left(10^{\circ} \mathrm{Bx}\right), 88.4 \mathrm{~g}$ water, 0.6 $\mathrm{g}$ protein, $10.5 \mathrm{~g}$ carbohydrates, $0.12 \mathrm{~g}$ fibers and $0.3 \mathrm{~g}$ ash with $0.41 \%$ acidity (Syed et al., 2012). Candies and jam which are prepared by drying the Malta fruit in the appropriate temperature and moisture conditions have also been consumed. Essential oil extracted from the fruit peels of malta have great therapeutic and cosmetic values. Powder prepared from peels of Malta is also used in various cosmetic products.

Malta contains minerals like Potassium and Calcium which enhance the immune system by enhancing the resistance against infections caused in blood. Malta also helps in rejuvenating the tissues and cells of the body. Due to its sweet flavor, sweet aroma and vitamin $\mathrm{C}$ rich source, it is used in various horticultural applications. It is an antioxidant with low calories and ample fiber and pectin content. Studies have find out that this fruit contains $47 \mathrm{kcal}$ energy, $0.94 \mathrm{~g}$ protein, $0.12 \mathrm{~g}$ fat, $2.4 \mathrm{~g}$ dietary fiber, 53.2 milligrams vitamin $\mathrm{C}$, 0.1-milligram iron, 14-milligram phosphorus, 10-milligram magnesium, and 181-milligram potassium per $100 \mathrm{~g}$ of malta fruit (USDA nutrient database, 2014). It exhibits many bioactive properties likeantibacterial, antifungal, antiobesity, cardiovascular activities, insecticidal activities etc. due to the presence of bioactive ingredients like- flavonoids, steroids, fatty acids, coumarins, peptides, carotenoids and other volatile compounds (Favela-Hernández et al., 2016). Due to its usage and health benefits, malta tree is also being recommended by the government for the various plantation activities especially in the hilly regions of Uttarakhand.

Despite being so rich in nutritional, medicinal and therapeutic values malta fruit is struggling hard in Uttarakhand just to properly reach to the markets. As the transportation plays a major role in pricing of any product, selling fresh fruits to the market doesn't fetch good prices to the producer due to the poor roads and transportation access in the remote areas. Lack of properly maintained and organized orchards is another major reason for its poor visibility and marketing. In general, malta trees are not managed in a proper manner for commercial production may be resulting to decrease in productivity. As the season of harvesting of malta fruits takes place during November to December, which is a severe winter season in this hilly area, this may also be a reason that a citrus fruit in winter may not tap the local market and reduces its likability for its consumption. Fruit management becomes tough due to the monkey problem which is very prevalent in hilly regions. As far as the marketing of malta fruit is concerned, the contractor or commission based marketing channel in preferred in the majority (Saxena and Singh, 2015). This marketing channel is least efficient and least profitable for the producer but it is preferred because producer gets a lump sum amount without being worried about the transportation and sale of malta fruit 
in the market but the most of the profit is taken away by the contractor. The perishability of this fruits leaves no choice but to sell it in cheap prices and the lack of proper post harvest units in the nearby areas of producers further adds up to problems of its marketing. Among all these the main problem still remains the lack of awareness of producers about its cultivation, orchard management, post harvesting and marketing channels. Inadequate data regarding its availability, production, management and value addition creates hurdles in the advance studies and research like the development of new and improved varieties or studies regarding increasing the productivity of malta fruit.

These problems need to be sorted out from the many aspects with joint involvement of the producers/farmers, cooperatives, Self-help groups, FPOs (Farmers Producer Organization), researcher institutes/ agricultural universities and the extension workers. Producers of malta fruits need to be aware regarding various ongoing schemes providing the technical and financial support to the fruit growers of Uttarakhand. The knowledge regarding how its real marketing works is essential. In Uttarakhand, schemes are functioning to support the farmers and fruit growers, however, there is a need to exclusively include with key importance to malta. One such scheme is Horticulture mission for North east and Himalayan states (HMNEH) which provide financial assistance and subsidiary facilities for the establishment of nurseries, irrigation system, planting material, equipments, protected cultivation units like green house or shade net house, post harvest units for processing of harvest and its value addition. It also provides subsidies for horticultural mechanization and trainings to the marginal farmers and fruit growers of hilly regions including Uttarakhand. Another scheme is 'On farm water management' under National mission for Sustainable agriculture
(NMSA) which provide subsidy for the establishment of micro irrigation system for fruit crops in Uttarakhand. These schemes are especially focused towards the development of marginal and small fruit/plantation crop growers of Uttarakhand. Producers need to work with the village level cooperative and self help groups for its marketing instead of being dependent on the contractors. Cooperative groups based marketing channel have found to be more efficient and profitable to the producers as compared to contract based marketing. With these cooperatives, it is easy to form a proper market and a defined market price for its products. The post harvest units could be established by the village level cooperatives with the technical support by horticulture departments, agricultural universities and extension workers. Researchers, farmers the extension workers need to come together to train the producers of malta fruit for its better cultivation, operations, management, protection and marketing. The malta trees are growing mostly in kitchen gardens and home gardens with agricultural crops under agri-horticulture (agroforestry systems) therefore, there is need to conduct researches for most compatible, efficient and profitable agroforestry combinations and systems for malta growers.

\section{References}

Favela-Hernández J, González-Santiago O, Ramírez-Cabrera MA, Esquivel-Ferriño PC, Camacho-Corona M. (2016). Chemistry and Pharmacology of Citrus sinensis. Molecules, 21(2): 247. (doi: doi.org/10.3390/molecules21020247)

Saxena A, Singh A. (2015). Marketing of sweet orange (malta) in Uttarakhand. International Journal of Commerce and Business Management, 8(2): 290-295.

Shah NC. Citrus fruits in India- Part 1. (2014). The Scitech Journal, 1(12): 3036

Syed HM, Ghatge PU, Machewad G, Pawar 
S. (2012). Studies on Preparation of Squash from Sweet Orange. Open Access Scientific Reports, 1:311. (doi:10.4172/scientificreports.311)

USDA Nutrient Database. (2014). United
States Department of Agriculture, National Nutrient Database for Standard Reference Release 26, Fruits and Fruit Juices.

\section{How to cite this article:}

Suraj Goswami, Arvind Bijalwan and Kalpana. 2020. Malta (Citrus sinensis): An Important but Underrated Fruit of Uttarakhand, India. Int.J.Curr.Microbiol.App.Sci. 9(08): 2852-2855. doi: https://doi.org/10.20546/ijcmas.2020.908.320 